\title{
Agroforestry practices and its contribution to combat climate change in subtropical region of Pakistan
}

\author{
Suleman Shah ${ }^{1 *}$, Aamir Saleem ${ }^{1}$, Saeed Gulzar ${ }^{1}$, Arshad Mehmood \\ Malik $^{2}$ and Javed Iqbal Khattak ${ }^{3}$ \\ 1. Department of Forestry and Range Management, Pir Mehr Ali Shah Arid Agriculture University Rawalpindi \\ Punjab-Pakistan \\ 2. Department of Economics, Pir Mehr Ali Shah Arid Agriculture University Rawalpindi Punjab-Pakistan \\ 3. Department of Forestry, Shaheed Benazir Bhutto University Sheringal Dir Upper KPK-Pakistan \\ *Corresponding author's email: saayim77@gmail.com
}

Citation

Suleman Shah, Aamir Saleem, Saeed Gulzar, Arshad Mehmood Malik and Javed Iqbal Khattak. Agroforestry practices and its contribution to combate climate change in subtropical region of Pakistan. Pure and Applied Biology. Vol. 9, Issue 1, pp376-389. http://dx.doi.org/10.19045/bspab.2020.90042

\begin{tabular}{llll}
\hline \hline Received: 28/08/2019 & Revised: 31/10/2019 & Accepted: 01/11/2019 & Online First: 06/11/2019 \\
\hline \hline
\end{tabular}

\section{Abstract}

Agroforestry systems could have an indirect impact on Carbon (C) sequestrations by reducing the pressure on natural forests, which are the largest $\mathrm{C}$ sink in the terrestrial ecosystem. This research was conducted in subtropical region of Pakistan (Tehsil Takht Bhai District Mardan). Two types of sampling methodologies were used for data collection. A questionnaire was compiled for the collection of information on Agroforestry practices, while a stratified random sampling method was used to collect data and made measurements about carbon contents stored in these agroforestry systems. Total 15 trees species were found associated with agricultural practices belonging to 7 families. Four (4) species were belonging to Moraceae family. One (1) specie belonged to Meleiaceae, Myrtaceae and Simaroubaceae each, 4 species belonged to Fabaceae and 2 species belonged to Rhamnaceae family. Total area under Agroforestry practices was about 22,866.4 hectares. Major Agroforestry system was Agrisilviculture system under practice in 11433.2 hectares land area, followed by Silvopastoral system which occupied 6859.9 hectares while area covered by Agrisilvipastoral system was 4573.2 hectares. 275 farmers were interviewed. Through final analysis it was found that $67 \%$ farmers were practicing pure Agrisilviculture system, $21 \%$ farmers were in favor of Silvopastoral system and 12\% farmers practiced Agrisilvopastoral system. The greatest amount of carbon was stored by Silvopastoral system (76.33 t.ha ${ }^{-1}$ ) followed by Agrisilvopastoral system (68.05 t.ha' ${ }^{-1}$ ) while the least carbon was stored by Agrisilvicultural system (11.61 t.ha-1).

Keywords: Agroforestry practices; Agrisilviculture; Agrisilvipastoral; Biomass; Carbon stocks; Climate change; Silvopastoral

\section{Introduction}

Agroforestry is recognized as a fundamental science that has the potential to provide many of the environmental services and livelihoods needed to improve the economic condition of farmers and rural communities [1]. On the other hand, it had been claimed that agroforestry offers opportunities for 
improving agricultural land use systems, providing long-term benefits and reducing negative environmental impacts at local and global levels [2].

Agroforestry is a conventional method for combining trees with agricultural crops or pastures, so that it can benefit greatly from the management of the same land [3]. Vegetation with agricultural and pastoral activities on land, either in spatial or temporal order, so that there is an economic as well as an ecological interaction between them. The combination of trees, crops and/or animals into an agroforestry system has the ability to reduce soil infertility, erosion, improve aesthetics, water quality, increase biodiversity and store carbon $[2,4,5]$

The management of agricultural carbon sequestration systems had been reported as a partial solution to climate change [3]. Establishing and maintaining perennial vegetation to improve $\mathrm{C}$ sequestration is more cost effective that minimizes environmental and health risks compared to most other techniques. The perennial vegetation is more efficient than the annual vegetation as it distributes a higher amount of carbon underground and often prolongs the growing season [6].

Climate change through improving carbon sequestration and improving the system's ability to manage the harmful effects of changing climatic conditions can be achieved through the use of different Agroforestry systems. In the meantime, agroforestry is the best example of coping with the negative effects of climate change [7]. In addition, improved farming practices, can double crop yields, reduce greenhouse gas emissions and improve the soil carbon storage capacity (SOC) [8].

In addition, agroforestry systems could have an indirect impact on $\mathrm{C}$ sequestrations by reducing the pressure on natural forests, which are the largest $\mathrm{C}$ sink in the terrestrial ecosystem. It had been estimated that 1 hectare of sustainable agroforestry in tropical regions can potentially save 5 to 20 hectares of deforestation [9]. This report further argued that agroforestry systems can bind carbon at average time rates of 0.2 to $3.1 \mathrm{Mg}$ $\mathrm{C} \mathrm{ha}^{-1}$. On a global scale, it was estimated that agroforestry could be implemented on 585 to 1275 x 106 hectares of technically suitable land and that these systems could store 12 to $228 \mathrm{Mg} \mathrm{C} \mathrm{ha}^{-1}$ under the prevailing climatic and edaphic conditions. Average carbon storage through forestry practices had been estimated to be 9, 21, 50 and $63 \mathrm{mg} \mathrm{C}^{-1}$ in semi-arid, sub-humid, humid and temperate regions. For small-scale agroforestry systems in the tropics, the possible $\mathrm{C}$ sequestration rates are between 1.5 and $3.5 \mathrm{mg} \mathrm{C} \mathrm{ha}^{-1} \mathrm{y}^{-1}$. This study provides basic findings about agroforestry systems in carbon sequestration and their importance in combating climatic change. With addition, that it would clarify the stress minimizes on natural forest through enhanced agroforestry systems.

\section{Materials and methods}

Present study was conducted in the subtropical region of Pakistan, Tehsil Takht Bhai District Mardan KPK (Figure 1). It is in the subtropical zone; its geographical coordinates was $34^{\circ} 16^{\prime} 55^{\prime \prime} \mathrm{N}$ and $071^{\circ} 55^{\prime}$ 42" E. Total area of Tehsil Takht Bhai was $404 \mathrm{~km}^{2}$ (40400 ha). Altitude/Elevation of the study area ranges from 1120 feet to 1430 feet above sea level. Average temperature in Tehsil Takht Bhai is $22.2^{\circ} \mathrm{C}$; while the annual rainfall averages to $559 \mathrm{~mm}$. Study area was under different practices. Land covered by infrastructure was about 23\% (9,292 hectare). Similarly, water points had covered an area of $0.4 \%$ (161.6 hectares) non-cultivated area was $14 \% \quad(5,656$ hectare $)$ other miscellaneous uses $6 \%(2,424$ hectares $)$ while the cultivated or cropped land which support the agroforestry practices was $56.6 \%$ $(22,866.4$ hectares) of its total area. (Figure 2). 


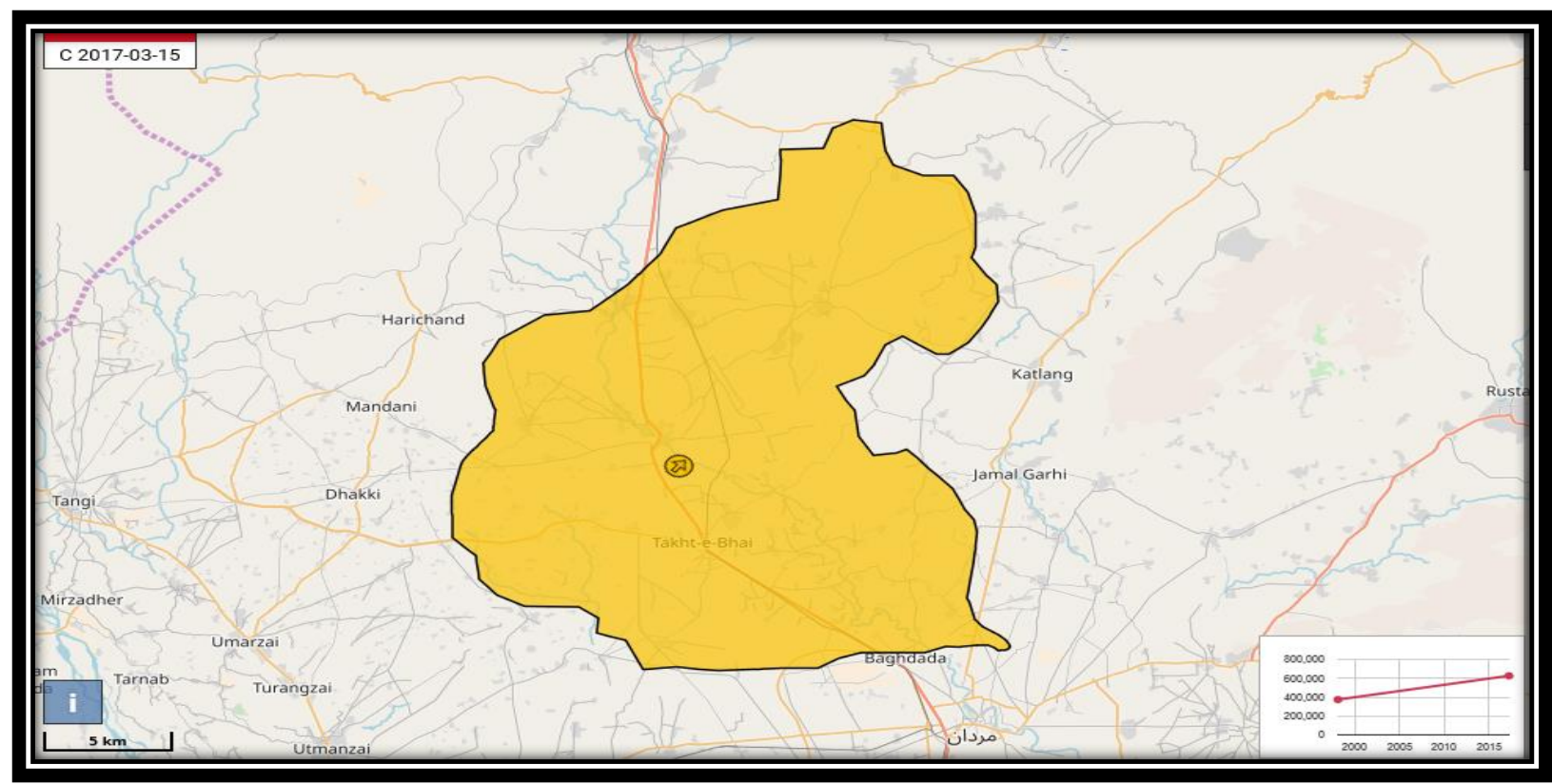

Figure 1. Map of the study area

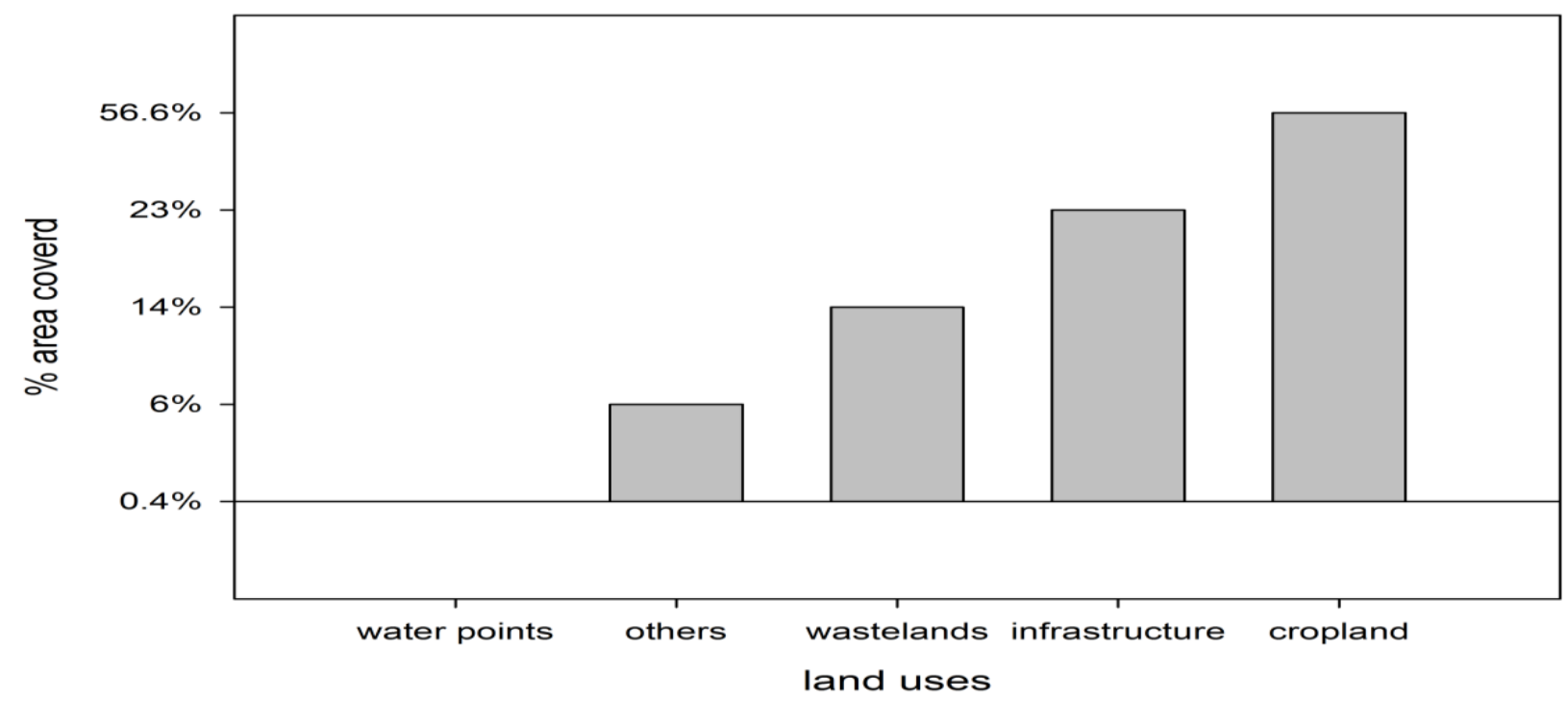

Figure 2. Land use of Study area

\section{Research design}

Two types of sampling methodologies were used for data collection in this research study. A questionnaire was compiled for the collection of information on agroforestry practices, while a stratified random sampling method was used to collect data on the carbon contents stored in these agroforestry systems. Study area was divided on the basis of union councils. Thereafter, in each union council, a sample of each agroforestry system (Agrisilvicultural, Silvopastoral and Agrisilvopastoral System) was made. The entire Tehsil was divided into 17 union councils. Three samples were taken in each union council. The total number of sampling plots was 51.

Sampling plot selection and size (For diameter at breast height (DBH) and height measurement) 
The samples were randomly selected in each union council in different agroforestry systems. The plot was square with a fixed dimension of $100 \times 100 \mathrm{~m}^{2}$ [10] in linear guard belt border plantations, while for block plantations the dimensions of the sample plot were $33 \times 33 \mathrm{~m}^{2}$. Using the Global Positioning System (GPS), elevation and coordinates of the individual sample plots were taken. The size of each sample plot was 1 and 0.1 ha, respectively.

Measurement of tree volume $\left(\mathrm{m}^{3}\right)$

Tree volume was measured from tree diameter $(\mathrm{cm})$ at diameter at breast height $(\mathrm{DBH})$ and height $(\mathrm{m})$. Height was taken from Dia-height ratio table present in Divisional forest office. Diameter tape and caliper were used for Diameter measurement. Volume of total tree $\mathrm{m}^{3} \mathrm{ha}^{-1}$ present in the study area was calculated by using the following formulae [11].

$\mathrm{V}\left(\mathrm{m}^{3} \mathrm{ha}^{-1}\right)=\mathrm{AHxFFxSD}$

As,

$\mathrm{V}=$ volume of trees $\left(\mathrm{m}^{3}\right)$

$A=$ cross sectional area at breast height point $\left(\mathrm{m}^{2}\right)$

$\mathrm{H}=$ height $(\mathrm{m})$

$\mathrm{FF}=$ form factor and

$\mathrm{SD}=$ Stem Density $\left(\right.$ ha $\left.^{-1}\right)$

\section{Measurement of stem biomass}

Stem biomass was further estimated by multiplying BWD (Basic Wood Density) $\mathrm{kg} \cdot \mathrm{m}^{-3}$ and tree volume $\left(\mathrm{m}^{3}\right)$. The value of Basic Wood Density was taken from current literature. For the estimation of biomass, following formulae was used.

SB $\left(\mathrm{t} \mathrm{ha}^{-1}\right)=$ BWD $\left(\mathrm{kg} / \mathrm{m}^{3}\right) \times \mathrm{TV}\left(\mathrm{m}^{3} \mathrm{ha}^{-}\right.$ $\left.{ }^{1}\right) / 1000$

Where,

$\mathrm{SB}=$ stem biomass

$\mathrm{BWD}=$ basic wood density and

$\mathrm{TV}=$ tree volume

Estimation of trees total biomass and carbon stocks

Total tree biomass $\left(\mathrm{t} \mathrm{ha} \mathrm{h}^{-1}\right)$ was calculated from stem biomass and biomass expansion factor (BEF). Total biomass was calculated using formulae below. BEF is the contribution of branches leaves and roots biomass to the total biomass of a tree [11].

TTB $\left(\mathrm{t} \mathrm{ha}^{-1}\right)=\mathrm{SB}\left(\mathrm{t} \mathrm{ha}^{-1}\right) \times \mathrm{BEF}$

Where,

$\mathrm{TTB}=$ total trees biomass

$\mathrm{SB}=$ stem biomass and

$\mathrm{BEF}=$ biomass expansion factor

Wile for carbon stocks estimation, total biomass was multiplied with the conversion factor of 0.5 which had been proved globally as it is the partial of fresh biomass [11]. Total carbon stocks were estimated by using formulae below.

Total C-stocks $\left(\mathrm{t} \mathrm{ha}^{-1}\right)=$ Total biomass $\left(\mathrm{t} \mathrm{ha}^{-}\right.$ 1) $\mathrm{x} 0.5$

Measurement of under story vegetation, deadwood and litter biomass

For understory vegetation and deadwood litter biomass, $1 \mathrm{~m}^{2}$ plots were lay down in each sample plot through fixed dimensional quadrate for estimation of grasses, deadwood and litter biomass. Fresh weight of grasses, deadwood and litter was estimated of all sample plots. $1 \mathrm{~kg}$ of green weight was taken and dried in an oven for 48 hours at 72 degree Celsius temperature. Finally, dry weight was taken and proceeds ahead.

\section{Statistical analysis}

For statistical analysis of data, various software was used. The statistics were organized in MS Excel, Univariate statistics was carried out in PAST while graphical representation was done in sigma plot version 14.

\section{Results}

GPS Co-ordinates and elevation of each sample plot

Total 51 sample plot were taken in the study area. Study area was divided on the basis of union councils. Total numbers of union councils were 17. In each union council different agroforestry systems were studied. One sample plot was taken in each agroforestry system. Elevation and GPS co- 
ordinates of each sample plot were taken with the help of GPS (Global Positioning System) showed in (Table 1).

Table 1. GPS Co-Ordinates and Elevation of each Sample Plot

\begin{tabular}{|c|c|c|c|c|c|c|c|}
\hline $\begin{array}{l}\text { Plot. } \\
\text { No }\end{array}$ & $\begin{array}{l}\text { Elevation } \\
\text { (ft) }\end{array}$ & Latitude & Longitude & $\begin{array}{l}\text { Plot } \\
\text {.No }\end{array}$ & $\begin{array}{c}\text { Elevation } \\
\text { (ft) }\end{array}$ & Latitude & Longitude \\
\hline 1 & 1201 & N $3418^{\prime} 58^{\prime \prime}$ & $071^{\circ} 51^{\prime} 33^{\prime \prime}$ & 2 & 1211 & $34^{\circ} 19^{\prime} 17^{\prime \prime}$ & $071^{\circ} 52^{\prime} 12^{\prime \prime}$ \\
\hline 3 & 1202 & $34^{\circ} 19^{\prime} 31^{\prime \prime}$ & 071 & 4 & 1206 & $34^{\circ} 20^{\prime} 13^{\prime \prime}$ & $071^{\circ} 51^{\prime} 31^{\prime \prime}$ \\
\hline 5 & 1102 & $34^{\circ} 19^{\prime} 08^{\prime \prime}$ & $071^{\circ} 49^{\prime} 45^{\prime \prime}$ & 6 & 1063 & $34^{\circ} 19^{\prime} 31^{\prime \prime}$ & $071^{\circ} 50^{\prime} 27^{\prime \prime}$ \\
\hline 7 & 1181 & $34^{\circ} 20^{\prime} 22^{\prime \prime}$ & $071^{\circ} 52^{\prime} 41^{\prime \prime}$ & 8 & 1144 & $34^{\circ} 20^{\prime} 16^{\prime \prime}$ & $071^{\circ} 53^{\prime} 47^{\prime \prime}$ \\
\hline 9 & 1197 & $34^{\circ} 21^{\prime} 10^{\prime \prime}$ & $071^{\circ} 53^{\prime} 57^{\prime \prime}$ & 10 & 1174 & $34^{\circ} 18^{\prime} 7^{\prime \prime}$ & $71^{\circ} 51^{\prime} 59^{\prime \prime}$ \\
\hline 11 & 1145 & $34^{\circ} 17^{\prime} 18^{\prime \prime}$ & $71^{\circ} 52^{\prime} 28^{\prime \prime}$ & 12 & 1174 & $34^{\circ} 17^{\prime} 5^{\prime \prime}$ & $71^{\circ} 53^{\prime} 8^{\prime \prime}$ \\
\hline 13 & 1079 & $34^{\circ} 17^{\prime} 2^{\prime \prime}$ & $71^{\circ} 53^{\prime} 59^{\prime \prime}$ & 14 & 1079 & $34^{\circ} 17^{\prime} 3^{\prime \prime}$ & $71^{\circ} 54^{\prime} 0^{\prime \prime}$ \\
\hline 15 & 1151 & $34^{\circ} 19^{\prime} 1 "$ & $71^{\circ} 54^{\prime} 39^{\prime \prime}$ & 16 & 1082 & $34^{\circ} 15^{\prime} 23^{\prime \prime}$ & $71^{\circ} 54^{\prime} 44^{\prime \prime}$ \\
\hline 17 & 1099 & $34^{\circ} 15^{\prime} 16^{\prime \prime}$ & $71^{\circ} 54^{\prime} 56^{\prime \prime}$ & 18 & 1072 & $34^{\circ} 15^{\prime} 0^{\prime \prime}$ & $71^{\circ} 54^{\prime} 48^{\prime \prime}$ \\
\hline 19 & 1069 & $34^{\circ} 15^{\prime} 36^{\prime \prime}$ & $71^{\circ} 55^{\prime} 36^{\prime \prime}$ & 20 & 1075 & $34^{\circ} 15^{\prime} 30^{\prime \prime}$ & $71^{\circ} 55^{\prime} 53^{\prime \prime}$ \\
\hline 21 & 1099 & $34^{\circ} 15^{\prime} 56^{\prime \prime}$ & $71^{\circ} 55^{\prime} 43^{\prime \prime}$ & 22 & 1177 & $34^{\circ} 18^{\prime} 40^{\prime \prime}$ & $71^{\circ} 54^{\prime} 31^{\prime \prime}$ \\
\hline 23 & 1184 & $34^{\circ} 18^{\prime} 52^{\prime \prime}$ & $71^{\circ} 54^{\prime} 43^{\prime \prime}$ & 24 & 1173 & $34^{\circ} 18^{\prime} 10^{\prime \prime}$ & $71^{\circ} 54^{\prime} 14^{\prime \prime}$ \\
\hline 25 & 1154 & $34^{\circ} 19^{\prime} 47^{\prime \prime}$ & $71^{\circ} 55^{\prime} 29^{\prime \prime}$ & 26 & 1145 & $34^{\circ} 19^{\prime} 58^{\prime \prime}$ & $71^{\circ} 56^{\prime} 1^{\prime \prime}$ \\
\hline 27 & 1177 & $34^{\circ} 19^{\prime} 14^{\prime \prime}$ & $71^{\circ} 56^{\prime} 47^{\prime \prime}$ & 28 & 1122 & $34^{\circ} 19^{\prime} 43^{\prime \prime}$ & $71^{\circ} 57^{\prime} 13^{\prime \prime}$ \\
\hline 29 & 1158 & $34^{\circ} 19^{\prime} 37^{\prime \prime}$ & $71^{\circ} 57^{\prime} 29^{\prime \prime}$ & 30 & 1170 & $34^{\circ} 19^{\prime} 14^{\prime \prime}$ & $71^{\circ} 56^{\prime} 26^{\prime \prime}$ \\
\hline 31 & 1116 & $34^{\circ} 16^{\prime} 17^{\prime \prime}$ & $71^{\circ} 56^{\prime} 47^{\prime \prime}$ & 32 & 1093 & $34^{\circ} 15^{\prime} 02^{\prime \prime}$ & $71^{\circ} 56^{\prime} 19^{\prime \prime}$ \\
\hline 33 & 1090 & $34^{\circ} 15^{\prime} 32^{\prime \prime}$ & $71^{\circ} 56^{\prime} 42^{\prime \prime}$ & 34 & 1440 & $34^{\circ} 17^{\prime} 16^{\prime \prime}$ & $71^{\circ} 56^{\prime} 09^{\prime \prime}$ \\
\hline 35 & 1163 & $34^{\circ} 17^{\prime} 20^{\prime \prime}$ & $71^{\circ} 55^{\prime} 39^{\prime \prime}$ & 36 & 1323 & $34^{\circ} 17^{\prime} 22^{\prime \prime}$ & $71^{\circ} 56^{\prime} 04^{\prime \prime}$ \\
\hline 37 & 1281 & $34^{\circ} 23^{\prime} 00^{\prime \prime}$ & $71^{\circ} 59^{\prime} 03^{\prime \prime}$ & 38 & 1267 & $34^{\circ} 22^{\prime} 55^{\prime \prime}$ & $71^{\circ} 58^{\prime} 55^{\prime \prime}$ \\
\hline 39 & 1234 & $34^{\circ} 23^{\prime} 12^{\prime \prime}$ & $71^{\circ} 59^{\prime} 02^{\prime \prime}$ & 40 & 1247 & $34^{\circ} 23^{\prime} 29^{\prime \prime}$ & $71^{\circ} 59^{\prime} 17^{\prime \prime}$ \\
\hline 41 & 1257 & $34^{\circ} 23^{\prime} 34^{\prime \prime}$ & $71^{\circ} 59^{\prime} 02^{\prime \prime}$ & 42 & 1239 & $34^{\circ} 23^{\prime} 25^{\prime \prime}$ & $71^{\circ} 59^{\prime} 19^{\prime \prime}$ \\
\hline 43 & 1263 & $34^{\circ} 23^{\prime} 44^{\prime \prime}$ & $71^{\circ} 55^{\prime} 28^{\prime \prime}$ & 44 & 1287 & $34^{\circ} 24^{\prime} 21^{\prime \prime}$ & $71^{\circ} 55^{\prime} 56^{\prime \prime}$ \\
\hline 45 & 1272 & $34^{\circ} 23^{\prime} 24^{\prime \prime}$ & $71^{\circ} 56^{\prime} 09^{\prime \prime}$ & 46 & 1349 & $34^{\circ} 25^{\prime} 21^{\prime \prime}$ & $71^{\circ} 59^{\prime} 26^{\prime \prime}$ \\
\hline 47 & 1330 & $34^{\circ} 24^{\prime} 35^{\prime \prime}$ & $71^{\circ} 59^{\prime} 52^{\prime \prime}$ & 48 & 1314 & $34^{\circ} 24^{\prime} 29^{\prime \prime}$ & $71^{\circ} 58^{\prime} 56^{\prime \prime}$ \\
\hline 49 & 1071 & $34^{\circ} 14^{\prime} 40^{\prime \prime}$ & $71^{\circ} 57^{\prime} 51^{\prime \prime}$ & 50 & 1064 & $34^{\circ} 13^{\prime} 50^{\prime \prime}$ & $71^{\circ} 57^{\prime} 47^{\prime \prime}$ \\
\hline 51 & 1080 & $34^{\circ} 14^{\prime} 55^{\prime \prime}$ & $71^{\circ} 57^{\prime} 21^{\prime \prime}$ & & & & \\
\hline
\end{tabular}

\section{Forest trees species and their identification}

Samples of forest trees were taken of each species and were put on herbarium sheets in the laboratory. Herbarium sheets were brought to the Department of Botanical Sciences, Abdul Wali Khan University Mardan for further identification. Total 15 species were found in the study area (rising with agriculture crops) belonging to 7 families. 4 species were belonging to Moraceae family. One species belonged to Meleiaceae, Myrtaceae and Simaroubaceae each, 4 species belonged to Fabaceae and 2 species belonged to Rhamnaceae family.

Species - Populous alba, Populous nigra, Morus nigra, Morus alba, Morus indica, 
Malia azedarach and Ailanthus altissima were mostly grown with food crops in which boundary plantation, alley cropping, shelter belt and block plantation practices were up to the mark. Details of species, their local names, botanical names and families were given in (Table 2).

Table 2. Forest trees species of the study area

\begin{tabular}{|c|c|c|c|}
\hline S/no & Botanical Name & Local Name & Family \\
\hline 1 & Morus nigra & Mulberry & \multirow{4}{*}{ Moraceae } \\
\hline 2 & Morus alba & Mulberry & \\
\hline 3 & Morus indica & Mulberry & \\
\hline 4 & Broussonetia papyrifera & Paper mulberry & \\
\hline 5 & Melia azedarach & China berry tree & Meleiaceae \\
\hline 6 & Ailanthus altissima & Tree of heaven & Simaroubaceae \\
\hline 7 & Eucalyptus camaldulensis & Safeeda & Myrtaceae \\
\hline 8 & Dalbergia sissoo & Sheesham & \multirow{4}{*}{ Fabaceae } \\
\hline 9 & Dalbergia latifolia & Sheesham & \\
\hline 10 & Acacia nilotica & Arabic tree & \\
\hline 11 & Acacia modesta & Arabic tree & \\
\hline 12 & Ziziphus mauritiana & Beer & \multirow{2}{*}{ Rhamnaceae } \\
\hline 13 & Ziziphus jujuba & Beer & \\
\hline 14 & Populous alba & Poplar & \multirow{2}{*}{ Salicaceae } \\
\hline 15 & Populous nigra & Poplar & \\
\hline
\end{tabular}

\section{Agroforestry systems of the study area}

The following agro-forestry systems were studied in the study area.

1. Agrisilvicultural system (ASS)

2. Silvopastoral system (SPS)

3. Agrisilvopastoral system (ASPS) or Mixed system

Area covered by agroforestry systems in the study area

There whole Tehsil supporting and keep maintaining enhanced agroforestry practices in which three major agroforestry systems were found - Agrisilvicultural system, Silvopastoral system and Agrisilvopastoral system. Total area under agroforestry practices was about 22866.4 hectares. Study area support different agroforestry systems with different proportion. The major agroforestry system was Agrisilviculture system which occupied about (11433.2 hectares), following by Silvopastoral system (6859.9 hectares) while the lower area covered by Agrisilvopastoral system was (4573.2 hectares) of its total cropped area. (Figure 3) showed contribution of different agroforestry systems in the study area.

\section{Farmer's approaches towards agroforestry systems}

To find out the farmer's approach towards agro-forestry systems, questionnaire was developed and 275 households/farmers were interviewed. Through final analysis it was found that maximum farmers $(67 \%)$ were practicing pure Agrisilviculture system, 21\% farmers were in favor of Silvopastoral system and $12 \%$ farmers practiced Agrisilvopastoral system (Figure 4). 


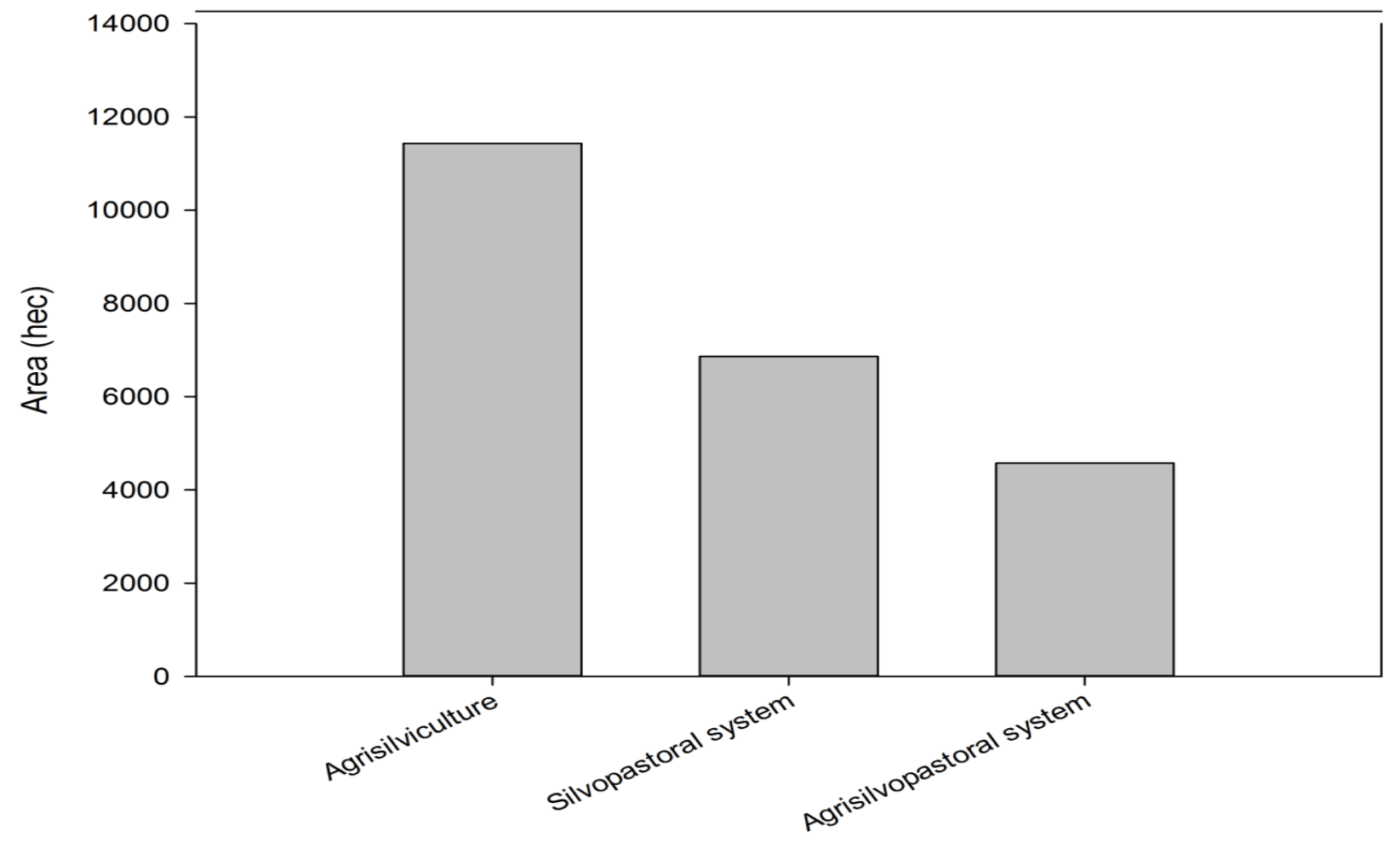

Agroforestry systems

Figure 3. Area occupancy of the study area by different agroforestry systems

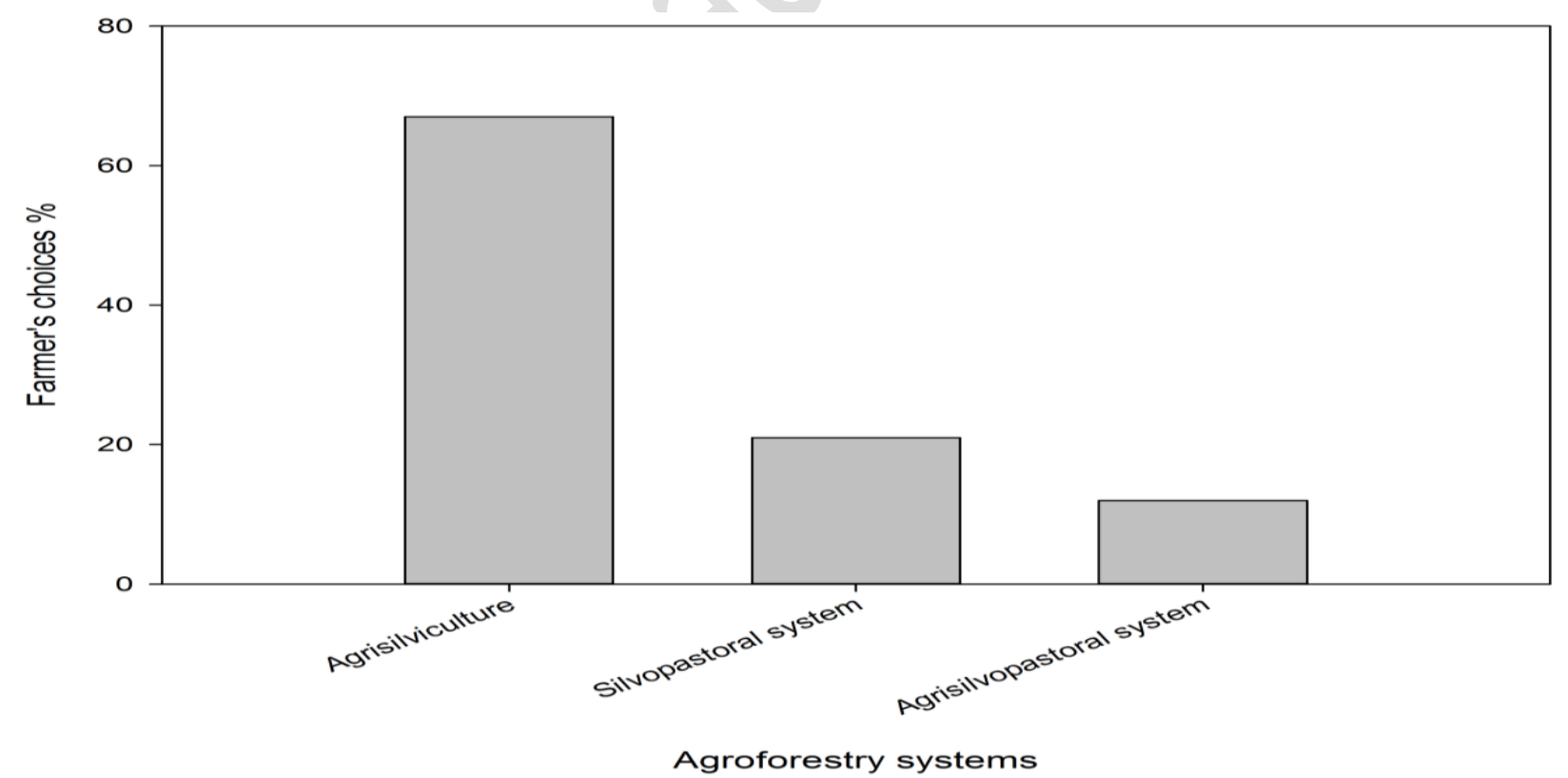

Figure Error! No text of specified style in document.. Farmers approaches towards agroforestry systems 
Union councils wise carbon stock tons ha $^{-1}$ in all agroforestry system

In each union council the different agroforestry system had different contribution in carbon sequestration. The minimum amount of carbon stored in UC Pir saddi, which was 112.64 t.ha $^{-1}$ (tons per hectare) while the richest union council was UC Pat Baba, which has stored maximum amount of carbon in all agroforestry systems (207.89 t.ha ${ }^{-1)}$ (Figure 5).

Minimum amount of carbon stored by Silvopastoral system in all union councils was recorded (37.15 t.ha-1) and maximum amount of carbon stored was (124.09 t.ha ${ }^{-1}$ ). (Table 3)
Greatest amount of carbon stored by the Silvopastoral system was recorded as 76.33 t.ha ${ }^{-1}$. Similarly, minimum $C$ sequestration by Agrisilvopastoral system was recorded as 29.99 t.ha $^{-1}$ and maximum amount of carbon sequestration was 115.52 t.ha $^{-1}$ while the average carbon stored by Agrisilvopastoral system was recorded as 68.05 t.ha $^{-1}$ (Table 3). Lowest contribution made by Agrisilvicultural system which was 4.35 t.ha $^{-}$ ${ }^{1}$ minimum and maximum amount was 35.21 t.ha $^{-1}$, the average carbon stored by Agrisilvicultural system was 11.61 t.ha $^{-1}$. Details of carbon sequestration by different agroforestry systems was given in (Figure 6).

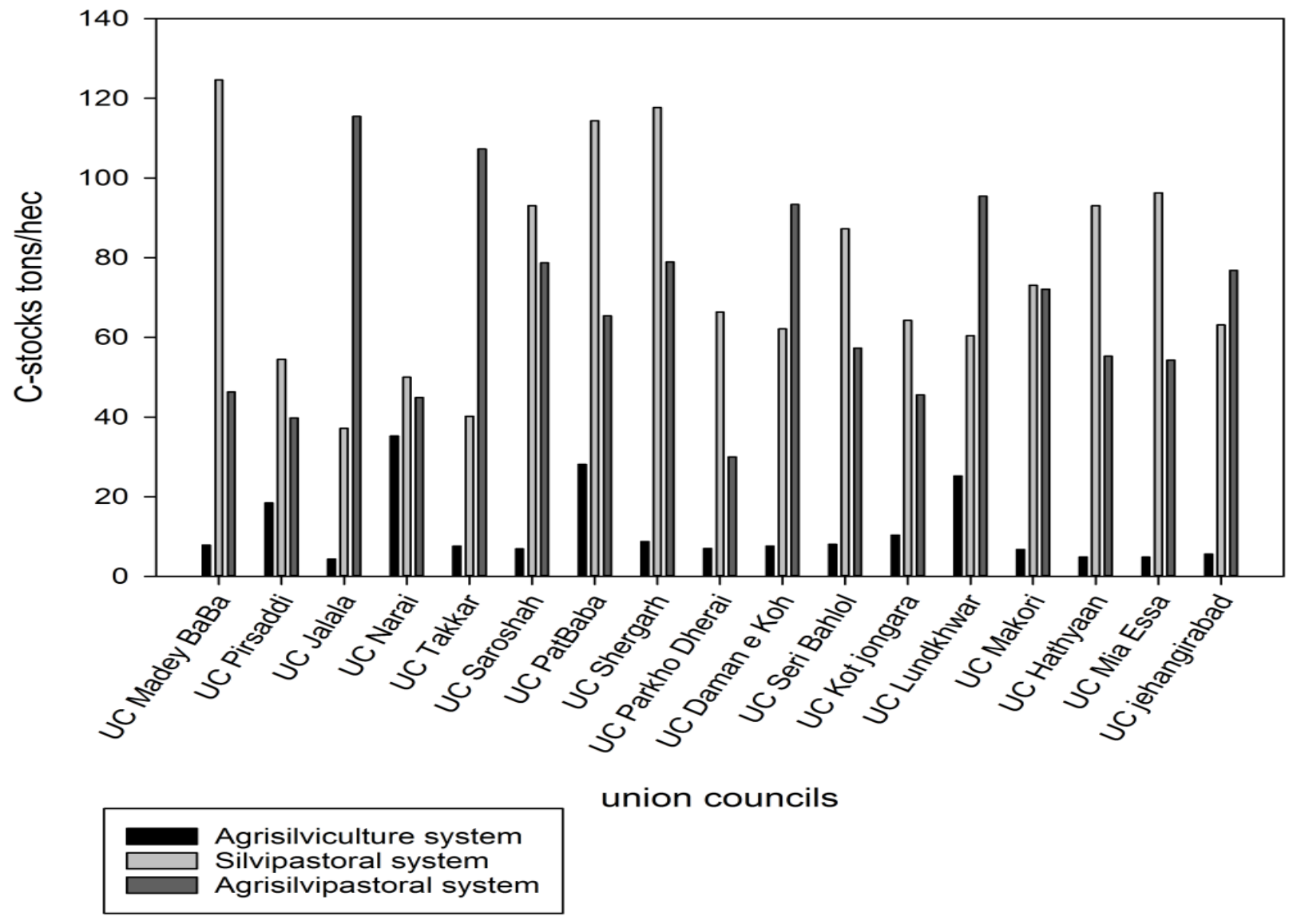

Figure 5. Union councils wise Carbon stocks t.ha' ${ }^{-1}$ in all agro-forestry systems 
Table 3. Details of Union council's wise Carbon stocks t.ha $\mathbf{A}^{-1}$ in all agro-forestry systems

\begin{tabular}{|c|c|c|c|c|c|}
\hline S/No & $\begin{array}{c}\text { Union } \\
\text { Councils }\end{array}$ & $\begin{array}{c}\text { A.S.S C-stocks } \\
\text { t.ha }^{-1}\end{array}$ & $\begin{array}{c}\text { S.P.S C- } \\
\text { stocks t.ha }^{-1}\end{array}$ & $\begin{array}{c}\text { A.S.P.S C- } \\
\text { stocks t.ha }^{-1}\end{array}$ & T.C-S t.ha $^{-1}$ \\
\hline 1 & UC Madey BaBa & 7.87 & 124.63 & 46.24 & 178.74 \\
\hline 2 & UC Pirsaddi & 18.41 & 54.45 & 39.78 & 112.64 \\
\hline 3 & UC Jalala & 4.35 & 37.15 & 115.52 & 157.02 \\
\hline 4 & UC Narai & 35.21 & 49.98 & 44.89 & 130.08 \\
\hline 5 & UC Takkar & 7.57 & 40.19 & 107.28 & 155.04 \\
\hline 6 & UC Saroshah & 6.92 & 93.06 & 78.74 & 178.73 \\
\hline 7 & UC PatBaba & 28.09 & 114.37 & 65.43 & 207.89 \\
\hline 8 & UC Shergarh & 8.74 & 117.69 & 78.94 & 205.36 \\
\hline 9 & UC Parkho Dherai & 6.97 & 66.37 & 29.99 & 103.33 \\
\hline 10 & UC Daman e Koh & 7.59 & 62.13 & 93.37 & 163.08 \\
\hline 11 & UC Seri Bahlol & 8.08 & 87.25 & 57.27 & 152.60 \\
\hline 12 & UC Kot jongara & 10.34 & 64.30 & 45.54 & 120.18 \\
\hline 13 & UC Lundkhwar & 25.19 & 60.46 & 95.46 & 181.12 \\
\hline 14 & UC Makori & 6.73 & 73.09 & 72.10 & 151.92 \\
\hline 15 & UC Hathyaan & 4.86 & 93.06 & 55.25 & 153.16 \\
\hline 16 & UC Mia Essa & 4.83 & 96.29 & 54.24 & 155.36 \\
\hline 17 & UC jehangirabad & 5.60 & 63.13 & 76.80 & 145.53 \\
\hline
\end{tabular}

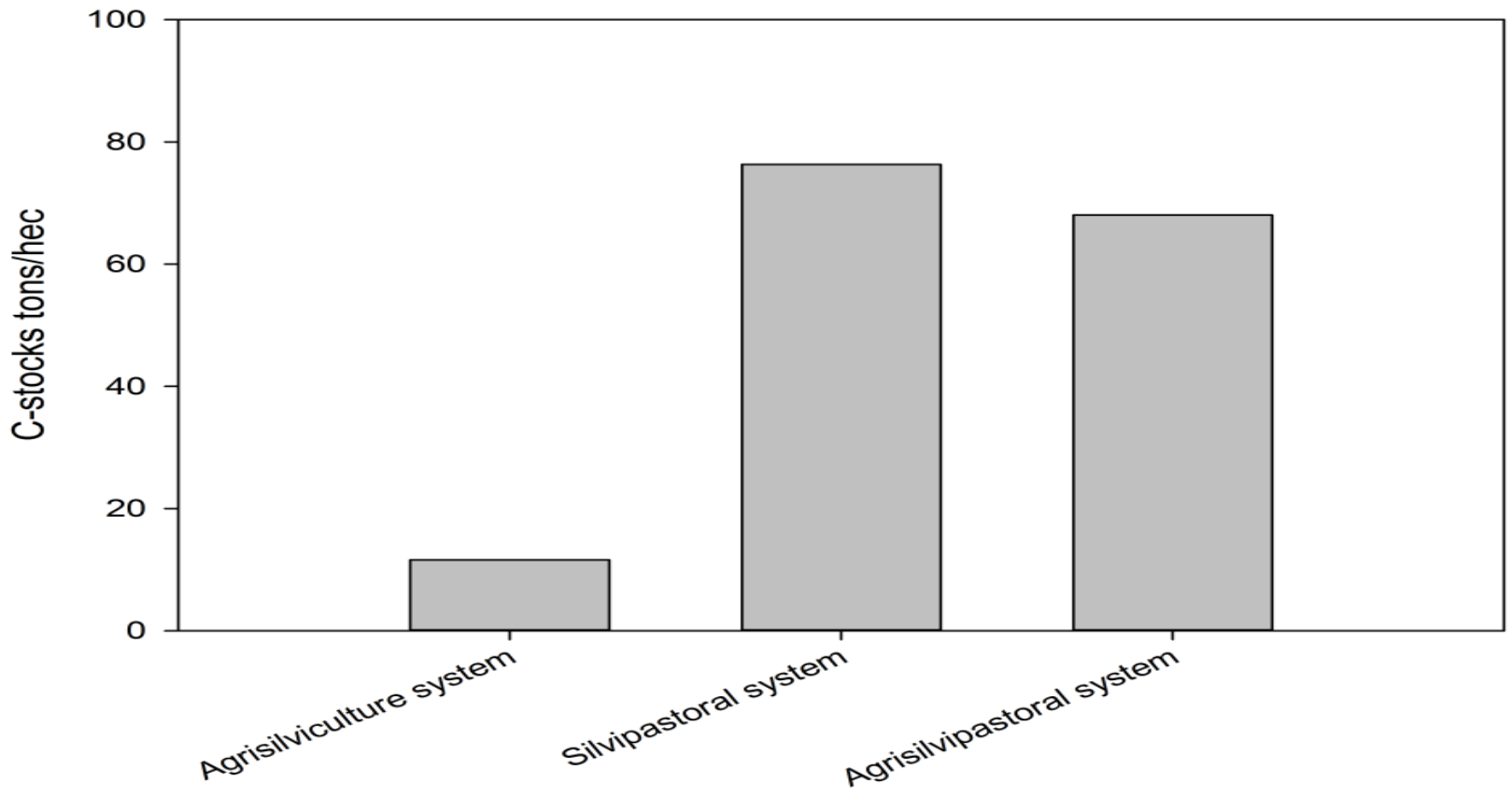

Agroforestry systems

Figure 6. Average carbon sequestration by each agro-forestry system 


\section{Carbon sequestration by different forest} tree species (tons ha-1)

In the whole study area, major carbon sequestration contribution was made by Populous (38.43 tha ${ }^{-1}$ ) while the minimum amount of carbon stored by acacia species was 0.22 t.ha $^{-1}$. Contribution made by Morus species was 4.08 t.ha $^{-1}$, Melia azedarach stored 4.08 t.ha $^{-1}$, Ailanthus altissima stored 3.26 t.ha $^{-1}$, Eucalyptus species stored 36.07 t.ha ${ }^{-1}$, Dalbergia species stored 22.64 t.ha $^{-1}$, Ziziphus species stored 2.25 t.ha $^{-1}$ and Broussonetia papyrifera stored 1.74 t.hac $^{-1}$. Graphical representation of carbon sequestration by different forest trees species was given in (Table 4).

Combine agroforestry systems carbon stocks (grasses, litter and deadwood) t. ha ${ }^{-1}$

For understory vegetation, subplots of $1 \mathrm{~m}^{2}$ were taken in each sample plot through quadrate of $\left(1 \mathrm{~m}^{2}\right)$ of fixed measurement for estimation of understory vegetation and deadwood litter biomass. The green weight of all vegetation was estimated of all example plots. One (1) $\mathrm{kg}$ of green weight was taken and dried in an oven for 48 hours at $72^{\circ} \mathrm{C}$ and their dry weight was estimated.

In all agroforestry systems, total 51 quadrates of $1 \mathrm{~m}^{2}$ were laid down. By final analysis it was calculated that lowest contribution of $\mathrm{C}$ storage done by a plot was $\left(0.41\right.$ t.ha $\left.^{-1}\right)$ and highest contribution was $\left(2.61\right.$ t.ha $\left.^{-1}\right)$ while the average carbon stocks per hectare was recorded as 1.8 t.ha $^{-1}$. Detailed calculation can be seen in (Table 5, Figure 7).

\section{Discussion}

In the study area, a total of 15 forest trees species were studied belonging to 7 families. All these forest trees species were fast growing species enhancing maximum biomass production from agricultural land with co-relation to agricultural crops. The agriculture zone sector still remains the largest sector as it played an important role in the national economy by contributing about $23.3 \%$ to the total GDP of Pakistan [12]. The combination of trees with the cash crops, food crops or grasses for livestock, brings maximum benefits for the human beings as well as to the land itself. The combinations of trees, farming crops and/or animals into an agro-forestry system has the ability to improve soil fertility, water quality, reduce erosion, enhance aesthetics, increase biodiversity and sequester carbon $[2,4,13]$ In the present study, it was found that the maximum practiced system of agro-forestry system was Agrisilvicultural system which was accepted and adopted by maximum farmers $(67 \%)$ as revealed in (Figure 4) followed by Silvopastoral system which was practiced by $21 \%$ farmers and the mixed or Agrisilvopastoral system was practiced by only $12 \%$ of the farmers in the study area. The major agro-forestry system was Agrisilviculture system which occupied about 11433.2 hectares, followed by Silvopastoral system which occupied 6859.9 hectares while the lower contribution made by Agrisilvopastoral system was 4573.2 hectares of its total cropped area (Figure 3 ).

Agro-forestry had been projected as approaches not only for adaption to climate change, but also for alleviation and addressing issues of food security and environmental degradation in agricultural systems. Agro-forestry is achieving recognition as an adaptation strategy, because traditional agricultural systems frequently include agroforestry practices [14]. In this regard, the implementation of agro-forestry is costly and more useful than other approaches [6].

Agricultural forestry is known to be of particular importance as a carbon sink strategy because of its applicability to agricultural land and the restoration of degraded land and reforestation programs $[15,11]$. Therefore, in the present study, it was concluded that the maximum amount of carbon was stored by Silvopastoral system (76.33 t.ha ${ }^{-1}$ ) which plays role just like an 
undisturbed natural forest. Similarly, the amount of carbon stored by mixed or Agrisilvopastoral system (68.05 ton ha') was also greater than the carbon stored by Agrisilvicultural system (11.61 t.ha ${ }^{-1}$ ) as shown in (Figure 6). It was because of the density of trees present per hectare. The number of trees on a piece of land increases the chances for capturing of atmospheric carbon.

In the study area, fast growing species like Poplus species, Eucalyptus species, and Ailanthus and Malia species has maximum carbon capturing capacity. The maximum accepted species for agro-forestry practices was Poplus species which had short rotation period of 6 to 12 years. In this short period of time the average carbon storage capacity of Poplus species was calculated to be 38.43 t.ha ${ }^{-1}$ (Table 4).

According to Noble et al. [16] by improving existing management strategies and practices (e.g. sustainable management of trees on agricultural land) in existing agroforestry, these practices could tie up an additional $12,000 \mathrm{Mg} \mathrm{C} \mathrm{y}^{-1}$ by 2010 and 17,000 $\mathrm{Mg} \mathrm{C} \mathrm{y}^{-}$ ${ }^{1}$ by 2040, In addition, 630 million hectares of the sequestering potential of $391,000 \mathrm{Mg}$ $\mathrm{C}^{-1}$ by 2010 and of $586,000 \mathrm{Mg} \mathrm{C} \mathrm{y}^{-1}$ by 2040. The present study concluded that the carbon sequestration potential of agroforestry systems is increasing in ascending order by advanced farming practices. It was calculated that the average carbon capture capacity for the Silvopastoral system was highest at 76.33 $\mathrm{t} \mathrm{ha}^{-1}$ compared to the Agrisilvopastoral system, which contains $68.05 \mathrm{C}$ t.ha ${ }^{-1}$. Lowest contribution from Agrisilvicultural system (11.61 t.ha-1) (Figure 6). Dixon [9] concluded that agroforestry sequester carbon with average rates of 0.2 to $3.1 \mathrm{Mg} \mathrm{C} \mathrm{ha}^{-1}$. On a global scale, it was estimated that agroforestry could be implemented on 585 to 1275 x 106 hectares of technically suitable land and that these systems could store 12 to $228 \mathrm{Mg} \mathrm{C} \mathrm{ha}^{-1}$ under prevailing climatic and edaphic conditions. Average carbon storage through agricultural and forestry practices had been estimated to be $9,21,50$ and $63 \mathrm{Mg}$ $\mathrm{C}$ ha $^{-1}$ in semi-arid, sub-humid, humid and temperate regions. For small-scale agroforestry systems in the tropics, the potential $\mathrm{C}$ sequestration rates were between 1.5 and $3.5 \mathrm{mg} \mathrm{C} \mathrm{ha}^{-1} \mathrm{y}^{-1}$.

With addition to live biomass present in an agro-forestry system, grasses, litter and deadwood biomass has also a key potential for carbon sequestration. The maximum amount of carbon stored by these under story deadwood, litter and grasses biomass in all agroforestry system (Figure 7) was calculated as $2.61 \mathrm{t}^{\mathrm{h} \mathrm{ha}^{-1}}$ and the lowest capacity for carbon sequestration was $0.41 \mathrm{t}^{-h^{-1}}{ }^{-1}$, while the average amount of carbon stocks present in all these agro-forestry system was calculated as 1.81 t.ha $^{-1}$.

Table 4. Details of Carbon sequestration by different forest trees species

\begin{tabular}{|c|c|c|c|}
\hline Species & \multirow{2}{*}{ Avg C-stocks t.ha $\mathbf{1}^{\mathbf{1}}$} & Species & Avg C-stocks t.ha $^{\mathbf{- 1}}$ \\
\hline M.alba & 4.08 & Ziziphus spp & 2.25 \\
\hline M.azedarach & 4.08 & Populous spp & 38.43 \\
\hline A.altissima & 3.26 & B.papyrifera & 1.74 \\
\hline Eucalyptus Spp & 36.07 & Acacia spp & 0.22 \\
\hline D.sissoo & 22.64 & & \\
\hline
\end{tabular}


Shah et al.

Table 5. Details of Combine agroforestry systems carbon stocks t.ha ${ }^{-1}$ (grasses, litter and deadwood)

\begin{tabular}{|c|c|c|c|c|c|c|}
\hline $\begin{array}{c}\text { Plot } \\
\text { no }\end{array}$ & System & $\begin{array}{l}\text { Grasses Oven } \\
\text { dry wt.Kg/m² }\end{array}$ & $\begin{array}{l}\text { Deadwood, litter Oven } \\
\text { dry wt.Kg/m }\end{array}$ & $\begin{array}{c}\text { Total } \\
\text { biomass } \\
\text { Kg/m² }\end{array}$ & $\begin{array}{c}\text { Total } \\
\text { biomass } \\
\text { Kg/ha }\end{array}$ & $\begin{array}{c}\text { C.sto } \\
\text { cks } \\
\text { t.ha' } \\
\end{array}$ \\
\hline 1 & A.S.S & 0.05 & 0.26 & 0.30 & 3030.66 & 1.51 \\
\hline 2 & $=$ & 0.05 & 0.04 & 0.08 & 830 & 0.41 \\
\hline 3 & $=$ & 0.03 & 0.16 & 0.19 & 1937.33 & 0.96 \\
\hline 4 & $=$ & 0.07 & 0.13 & 0.19 & 1935.3 & 0.96 \\
\hline 5 & $=$ & 0.06 & 0.16 & 0.22 & 2211.3 & 1.10 \\
\hline 6 & $=$ & 0.05 & 0.21 & 0.26 & 2575.3 & 1.28 \\
\hline 7 & $=$ & 0.06 & 0.26 & 0.31 & 3130.0 & 1.56 \\
\hline 8 & $=$ & 0.05 & 0.29 & 0.34 & 3429.33 & 1.71 \\
\hline 9 & $=$ & 0.05 & 0.35 & 0.40 & 3983.3 & 1.99 \\
\hline 10 & $=$ & 0.06 & 0.39 & 0.45 & 4496.0 & 2.24 \\
\hline 11 & $=$ & 0.06 & 0.24 & 0.30 & 2955.3 & 1.47 \\
\hline 12 & $=$ & 0.07 & 0.19 & 0.26 & 2616.7 & 1.30 \\
\hline 13 & $=$ & 0.06 & 0.33 & 0.39 & 3932.7 & 1.96 \\
\hline 14 & $=$ & 0.06 & 0.15 & 0.20 & 2074 & 1.03 \\
\hline 15 & $=$ & 0.06 & 0.15 & 0.21 & 2099.33 & 1.04 \\
\hline 16 & $=$ & 0.07 & 0.16 & 0.23 & 2259.3 & 1.12 \\
\hline 17 & $=$ & 0.06 & 0.09 & 0.15 & 1504.66 & 0.75 \\
\hline 18 & S.P.S & 0.09 & 0.21 & 0.29 & 2906.0 & 1.45 \\
\hline 19 & $=$ & 0.08 & 0.26 & 0.33 & 3358.66 & 1.67 \\
\hline 20 & $=$ & 0.07 & 0.29 & 0.36 & 3649.3 & 1.82 \\
\hline 21 & $=$ & 0.07 & 0.23 & 0.29 & 2918.0 & 1.45 \\
\hline 22 & $=$ & 0.06 & 0.39 & 0.45 & 4524.0 & 2.26 \\
\hline 23 & $=$ & 0.09 & 0.42 & 0.51 & 5085.3 & 2.54 \\
\hline 24 & $=$ & 0.11 & 0.28 & 0.38 & 3854 & 1.92 \\
\hline 25 & $=$ & 0.09 & 0.35 & 0.44 & 4440.66 & 2.22 \\
\hline 26 & $=$ & 0.10 & 0.19 & 0.28 & 2855.33 & 1.42 \\
\hline 27 & $=$ & 0.10 & 0.26 & 0.36 & 3563.3 & 1.78 \\
\hline 28 & $=$ & 0.10 & 0.21 & 0.30 & 3030.0 & 1.51 \\
\hline 29 & $=$ & 0.08 & 0.22 & 0.30 & 2996.0 & 1.49 \\
\hline 30 & $=$ & 0.09 & 0.36 & 0.45 & 4486.0 & 2.24 \\
\hline 31 & $=$ & 0.08 & 0.44 & 0.52 & 5208.7 & 2.60 \\
\hline 32 & $=$ & 0.10 & 0.37 & 0.47 & 4671.33 & 2.33 \\
\hline 33 & $=$ & 0.10 & 0.19 & 0.28 & 2847.3 & 1.42 \\
\hline 34 & $=$ & 0.10 & 0.21 & 0.31 & 3066.0 & 1.53 \\
\hline 35 & A.S.P.S & 0.14 & 0.37 & 0.50 & 5047.3 & 2.52 \\
\hline 36 & $=$ & 0.15 & 0.37 & 0.52 & 5224.7 & 2.61 \\
\hline 37 & $=$ & 0.15 & 0.24 & 0.4 & 3915.3 & 1.95 \\
\hline
\end{tabular}




\begin{tabular}{|c|l|l|l|l|l|l|}
\hline 38 & $=$ & 0.16 & 0.28 & 0.43 & 4398 & 2.19 \\
\hline 39 & $=$ & 0.16 & 0.29 & 0.46 & 4569.33 & 2.28 \\
\hline 40 & $=$ & 0.13 & 0.16 & 0.29 & 2900.67 & 1.45 \\
\hline 41 & $=$ & 0.16 & 0.15 & 0.30 & 3018.67 & 1.50 \\
\hline 42 & $=$ & 0.12 & 0.13 & 0.26 & 2552.67 & 1.27 \\
\hline 43 & $=$ & 0.12 & 0.13 & 0.25 & 2527.33 & 1.26 \\
\hline 44 & $=$ & 0.12 & 0.11 & 0.22 & 2235.33 & 1.11 \\
\hline 45 & $=$ & 0.12 & 0.12 & 0.23 & 2334 & 1.167 \\
\hline 46 & $=$ & 0.15 & 0.16 & 0.30 & 3047.33 & 1.52 \\
\hline 47 & $=$ & 0.13 & 0.08 & 0.21 & 2119.3 & 1.05 \\
\hline 48 & $=$ & 0.12 & 0.10 & 0.22 & 2210.7 & 1.10 \\
\hline 49 & $=$ & 0.13 & 0.28 & 0.40 & 4022.7 & 2.01 \\
\hline 50 & $=$ & 0.14 & 0.22 & 0.35 & 3580 & 1.79 \\
\hline 51 & $=$ & 0.15 & 0.35 & 0.49 & 4964 & 2.48 \\
\hline
\end{tabular}

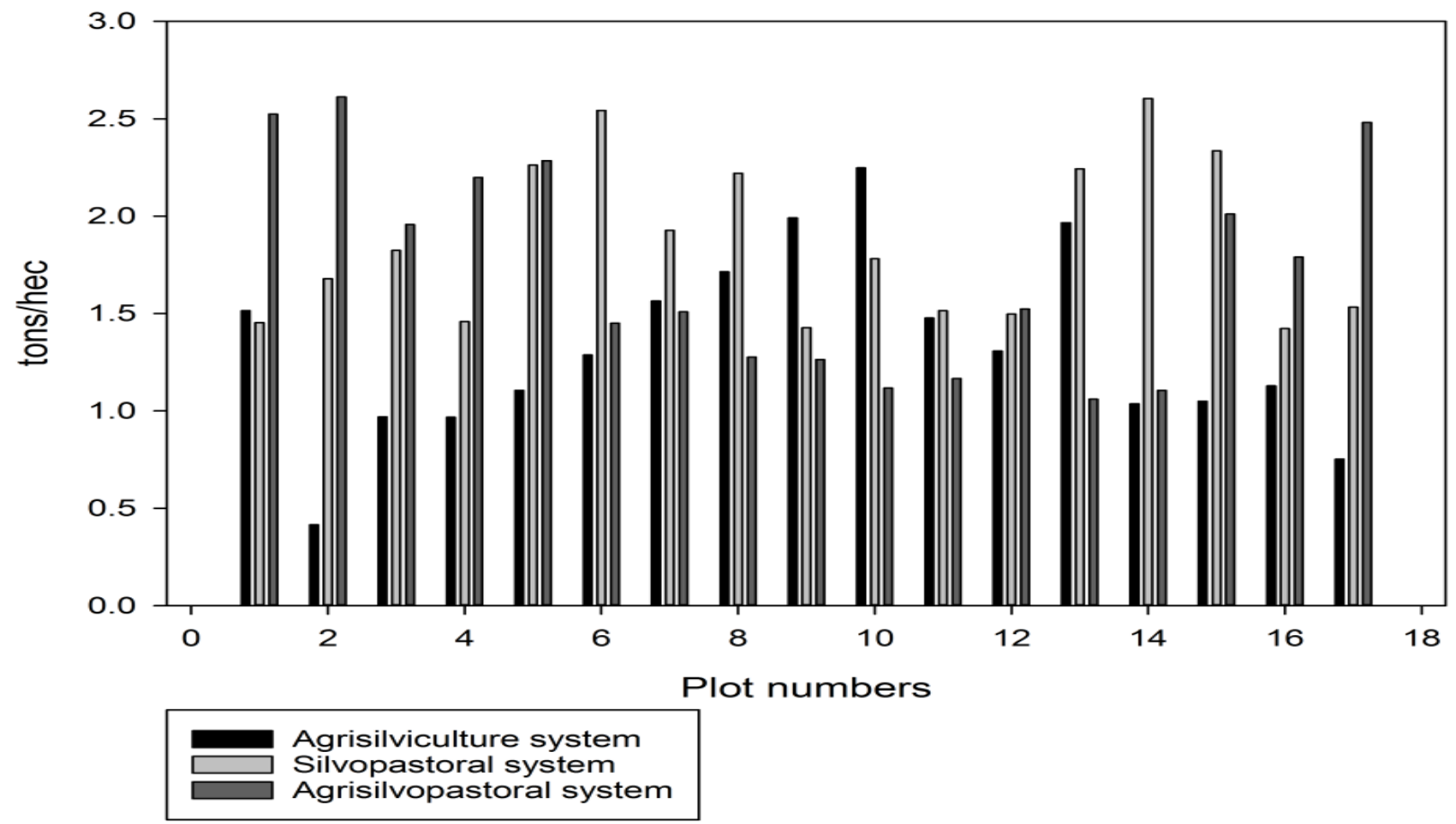

Figure 7. Combine agro-forestry systems carbon stocks (grasses, litter and deadwood) t.ha-1

\section{Conclusion}

Total area under agroforestry practices was about 22,866.4 hectares. Major Agroforestry system was Agrisilviculture system which was under practice in $11,433.2$ hectares land area, followed by Silvopastoral system which occupied 6859.9 hectares while area covered by Agrisilvipastoral system was 4573.2 hectares. $67 \%$ farmers were practicing pure Agrisilviculture system, 21\% farmers were in favor of Silvopastoral system and $12 \%$ farmers were liked to practice Agrisilvopastoral system. The present study concludes that the carbon sequestration potential of agroforestry systems is increasing in ascending order by advanced farming practices. It was calculated that the average carbon capture 
capacity for the Silvopastoral system was highest (76.33 $\mathrm{t} \mathrm{ha}^{-1}$ ) compared to the Agrisilvopastoral system, which contains $\left(68.05 \mathrm{t} \mathrm{ha}^{-1}\right) \mathrm{C}$. lowest contribution for $\mathrm{C}$ sequestration was studied in Agrisilvicultural system (11.61 t.ha $\left.{ }^{-1}\right)$. With addition to live biomass present in an agroforestry system, maximum amount of carbon stored by these under story (deadwood, litter and grasses) biomass in all agroforestry system was calculated as, (2.61 t.ha-1) while minimum amount of carbon sequestration was $\left(0.41 \mathrm{t}^{-h^{-1}}\right)$, while the average amount of carbon stocks present in all these agroforestry system was calculated as $\left(1.81 \mathrm{t}^{\mathrm{h}} \mathrm{ha}^{-1}\right)$.

Authors' contributions:

Conceived and designed the experiments: Shah S \& Malik AM, Performed the experiments: Saleem A, Iqbal J \& Shah S, Analyzed the data: Shah S, Saleem A \& Gulzar A, Contributed reagents/ materials/ analysis tools: Shah $\mathrm{S} \&$ Saleem A, Wrote the paper: Shah S.

\section{References}

1. Regmi BN (2003). Contribution of agroforestry for rural livelihoods: A case of Dhading District, Nepal. Paper presented at the International Conference on Rural Livelihoods, Forests and Biodiversity.

2. Garrett H, Rietveld W, Fisher RF, Kral D \& Viney M (2009). North American agroforestry: an integrated science and practice: American Society of Agronomy Madison. $J$ Mount Sci 11(1): 167-179.

3. Kalinganire A, Weber J, Uwamariya A \& Kone B (2007). Improving rural livelihoods through domestication of indigenous fruit trees in the parklands of the Sahel. Fruit Trees 10: 186-203.

4. Williams-Guillén K, Perfecto I \& Vandermeer J (2008). Bats limit insects in a neotropical agro-forestry system. Sci 320(5872): 70-70.

5. Garrity DP (2004). Agro-forestry and the achievement of the Millennium Development Goals. Agro-For Sys 61(1-3): 5-17.

6. Su Y, Lu J, Sujata M, Ashiq A \& Xu J (2013). Policy and institutions in adaptation to climate change: case study on tree crop diversity in China, Nepal, and Pakistan. ICIMOD Working Paper (2013/3).

7. Verchot LV, Van Noordwijk M, Kandji S, Tomich T, Ong C, Albrecht A \& Palm C (2007). Climate change: linking adaptation and mitigation through agro-forestry. Mitig and Adap Stra for Glo Change 12(5): 901918.

8. Branca G, Lipper L, McCarthy N \& Jolejole MC (2013). Food security, climate change, and sustainable land management. A review. Agro For Sustain Develop 33(4): 635-650.

9. Dixon R (1995). Agroforestry systems: sources of sinks of greenhouse gases? Agrofor Sys 31(2): 99-116.

10. Antle JM, Stoorvogel JJ \& Valdivia RO (2007). Assessing the economic impacts of agricultural carbon sequestration: terraces and agro-forestry in the Peruvian Andes. Agric Ecosys \& Envi 122(4): 435-445.

11. Ahmad A \& Nizami SM (2015). Carbon stocks of different land uses in the Kumrat valley, Hindu Kush Region of Pakistan. $J$ fores Res 26(1): 57-64.

12. Iqbal $M$, Ahmad $M$, Abbas $K$ \& Mustafa $K$ (2003). The impact of institutional credit on agricultural production in Pakistan [with comments]. The Pak Devel Rev 469-485.

13. Nair $P$ (2012). Carbon sequestration studies in agro-forestry systems: a reality-check. Agro-for Sys 86(2): 243-253.

14. Liang A, Yang X, Zhang X, McLaughlin N, Shen Y \& Li W (2009). Soil organic carbon changes in particle-size fractions following cultivation of Black soils in China. Soil and Tillage Res 105(1): 21-26.

15. Cairns MA \& Meganck RA (1994). Carbon sequestration, biological diversity, and sustainable development: integrated forest management. Env Mgt 18(1): 13-22.

16. Noble I, Bolin B, Ravindranath N, Verardo D \& Dokken D (2000). Land use, land use change, and forestry: Cambridge University Press. 